\title{
MASLAHAH MUNFARIDAH SEBAGAI JUSTIFIKASI \\ DALAM PENGAMALAN HUKUM ISLAM
}

\author{
Maulana Ni'ma Alhizbi \\ KUA Kecamatan Banyusari, Karawang Jawa Barat \\ Email :maulanaalhizbi@gmail.com
}

\begin{abstract}
Humans as khalifatullah are provided by Allah with minds and qalbu, so they can differentiate mashlahah (good) from mafsadat (bad). The potential of minds, situation, condition, and environment of each person is different, that has made the mashlahah is different for each person. This study is aimed to determine the epistemological process of individual mashlahah to be a communal mashlahah. This research begins with the view that the door of ijtihad is always open to anyone who has the credibility to do so, and the notion that not every issue has been answered by previous fuqaha, and reaffirm Islam as the religion of rahmatan lil 'aalamiin This research applied the descriptive philosophical method, and used various books of scholars and experts that related to ushul fiqh, qaidah figh, and the objective of Islamic Law as data source. The results of this study show that epistemologically, individual welfare can be explored through understanding and analysis of two sources of Islamic law (the Qur'an and the Sunnah) about the ease in carrying out the legal provisions contained in it as stipulated in surah al-Baqarah verse 185 and 286 , by using ushul fiqh and fiqh rules. The hadith of the Prophet لا ضرر ولا ضرار is a legal basis that can provide information about individuals mashlahah that can be used as a standard for public selfare. By refers to illat factors of law in every person, a law can be applied only to people who have equal illat. If all humans have the same illat, then the law can be applied to all humans.
\end{abstract}

\section{Keywords:}

mashlahah, the objective of Islamic law, ushul figh, fiqh

\begin{abstract}
Abstrak
Manusia sebagai khalifatullah dibekali oleh Allah dengan akal dan qolbu, akal dapat berfungsi untuk mengetahui mana hal yang mashlahah (baik), dan mana yang mafsadat (buruk). Potensi akal, situasi, kondisi, dan lingkungan setiap orang berbeda-beda maka mashlahahnya pun akan berbeda pula satu sama lainnya. Penelitian ini bertujuan untuk memaparkan proses epistemologis kemaslahatan individu menjadi kemaslahatan yang umum serta dasar hukum yang melandasinya. Penelitian ini berawal dari pandangan bahwa pintu ijtihad selalu terbuka bagi setiap orang yang mempunyai kredibilitas untuk melakukannya, dan anggapan bahwa tidak setiap persoalan yang ada sekarang sudah dijawab oleh para fuqaha terdahulu, juga harus adanya pemikiran kembali terhadap Islam dan mengukuhkannya sebagai agama rahmatan lil 'aalamiin. Metode penelitian yang digunakan adalah metode filosofis deskriptif, dengan sumber data adalah kitab-kitab karya ulama dan para pakar ushul figh yang berhubungan dengan Tujuan Hukum Islam, Mashlahah, Qaidah Fiqh dan Qaidah Ushul Fiqh. Hasil penelitian menunjukan bahwa secara epistemologis, kemashlahatan perseorangan dapat digali melalui pemahaman dan analisis terhadap dua sumber hukum Islam (al-Qur'an dan al-Sunnah) tentang
\end{abstract}


kemudahan-kemudahan dalam menjalankan ketentuan hukum yang ada di dalamnya seperti dalam surat al-Baqarah ayat 185 dan 286, dengan menggunakan kaidah ushul figh dan kaidah figh untuk menjelaskan keduanya. Hadits Nabi لا ضرر ولا ضرار merupakan landasan hukum yang dapat memberikan keterangan tentang kemashlahatan individu yang bisa dijadikan standar dari kemashlahataan umum. Dengan melihat kepada faktor illat hukum pada setiap individu, hukum dapat diterapkan hanya kepada orang yang mempunyai persamaan dalam illat hukum. Apabila seluruh manusia memiliki illat hukum yang sama maka hukum dapat diberlakukan kepada seluruh manusia.

\section{Kata kunci:}

mashlahah, tujuan hukum Islam, ushul fiqh, fiqh

\section{Pendahuluan}

Islam sebagai agama yang rahmatan lil alamin dengan al-Qur'an dan Hadits sebagai pedomannya diturunkan oleh Allah SWT kepada Nabi Muhammad SAW melalui perantara Malaikat Jibril merupakan agama yang sempurna. Kesempurnaan Islam ini menjadikan umat Islam terbagi menjadi dua aliran besar. Abdullah Ahmed al-Na'im menggolongkannya kepada umat Islam yang mempunyai "komitmen" menerapkan syari'ah secara tuntas, termasuk dalam hukum publik, dan mereka yang bersedia menerima tuntutan revisi dan reformulasi berbagai aspek hukum itu secara signifikan. ${ }^{1}$

Ketika firman Tuhan yang berupa al-Qur'an dan Hadits Nabi tidak mungkin diproduksi lagi, problematika umat malah semakin banyak di zaman sekarang, dan permasalahan-permasalahan itu menuntut manusia untuk segera mencari kejelasan hukumnya. Di sinilah metode-metode ijtihad yang telah dipraktekkan oleh para imam madzhab diperlukan. Dengan metodologi ijtihad yang berbeda, maka hasil dari ijtihadnya itupun akan berbeda pula. Namun tetap yang menjadi tujuannya adalah menciptakan kemaslahatan bagi umat manusia.

Imam Al-Syatibi telah melakukan istiqra (penelitian) yang digali dari al-Qur'an maupun Hadits, yang menyimpulkan bahwa tujuan Hukum Islam (Maqâshid al-Syari'ah) di dunia ada lima hal, yang dikenal dengan al-Maqashid al-Khamsah, yaitu: (a) Memelihara agama (Hifdz al-Din), (b) Memelihara jiwa (Hifdz al-Nafs), (c) Memelihara keturunan dan kehormatan (Hifdz al-Nas/irdl), (d) Menjaga harta (Hifdz al-Mâl). e) Memelihara akal (Hifdz al-Aql), ${ }^{2}$

Seperti yang dikutip oleh Masdar Farid Mas'udi, menurut Al-Ghazali, seluruh ketentuan dalam syari'at Islam bermuara pada perlindungan lima aspek kehidupan tersebut. Dengan kata lain, semua aturan atau kebijakan yang bermuara pada perlindungan lima aspek kehidupan tersebut sudah sesuai dengan syari'at, benar, dan mulia dalam pandangan agama, baik ia ditegaskan secara eksplisit oleh teks wahyu maupun tidak. ${ }^{3}$

\footnotetext{
${ }^{1}$ Abdullah Ahmed al-Na'im, Dekontruksi Syari'ah, (Yogyakarta: LKis Grup, 2011), hlm. 5.

${ }^{2}$ A. Djazuli, Ilmu fiqh, cetakan ke-7, (Jakarta: Kencana Prenada Media Grup, 2010), hlm. 26

${ }^{3}$ Masdar Farid Mas'udi, Syarah UUD 1945 perspektif Islam, (Jakarta: PT. Pustaka Alvabet, Edisi Baru, 2013) hlm. 197
} 
Dalam filsafat hukum terdapat pembahasan mengenai tujuan hukum, para ahli hukum memberikan pandangan mereka tentang hal ini, diantaranya adalah Roscoe Pound yang berpendapat bahwa hukum bertujuan untuk meliputi ketertiban guna mencapai keadilan dan sebagai alat pembaharuan masyarakat. Aliran positivisme hukum berpendapat bahwa hukum bertujuan untuk menciptakan kepastian hukum, Adapun Jeremy Benthamn mengatakan bahwa tujuan hukum adalah untuk kebahagiaan. ${ }^{4}$

Dari pendapat di atas baik yang berpandangan secara Islam maupun Barat, dapat disimpulkan secara sederhana bahwa tujuan hukum adalah menjaga kemaslahatan bagi mukallaf (orang yang dibebani hukum) yang sejalan dengan sumber hukum Islam.

Sebelumnya harus dibedakan antara kemaslahatan sebagai tujuan hukum dan kemaslahatan sebagai metodologi pengambilan hukum yang digunakan untuk ijtihad (mengeluarkan hukum dari dalil-dalilnya yang terperinci). Adapun maslahat yang dijadikan tujuan hukum adalah maslahat yang terjewantahkan dalam Maqoshid al-Syari'ah, sedangkan maslahat yang merupakan metode berijtihad adalah konsep mashlahah mursalah yang digunakan oleh Malikiyah. Dan yang akan dibahas lebih jauh oleh penulis adalah kemaslahatan yang merupakan tujuan dari hukum.

Menurut penjelasan Abdul Karim Zaidan sebagai mana yang dikutip oleh Ramli S.A. bahwa Imam Malik beserta pengikutnya serta Imam Ahmad menjadikan maslahah mursalah sebagai dalil hukum dan hujjah dalam menetapkan hukum. Imam Muhammad Abu Zahrah menyebutkan bahwa Imam Malik dan pengikutnya merupakan pencetus dan menyuarakan maslahah mursalah sebagai dalil hukum dan hujjah syari'ah. Sedangkan Imam Ghazali menerima maslahah mursalah sebagai dalil hukum dan hujjah syari'ah dengan ketentuan maslahahnya harus dharûriyat qath'iyah dan kulliyah. Wahbah Zuhaili berpendapat bahwa ulama yang menerima maslahah mursalah sebagai dalil hukum dan hujjah syari'ah adalah ulama-ulama Malikiyah dan Hanabillah, sedangkan golongan Hanafiyah menerima maslahah mursalah sebagai dalil hukum melalui jalan istihsan. ${ }^{5}$

Najmuddin Al-Thufi adalah seorang ahli hukum di kalangan madzhab Hambali yang pendapatnya dalam bidang Maslahah dipandang paling berani dan kontroversial. Ia mendahulukan maslahat dari nash-nash qath'i apabila keduanya bertentangan. Al-Thufi telah mengemukakan pendapatnya dan hujjah-hujjah-nya ketika menjelaskan hadis arba'in karya Al-Nawawi di bawah hadis "Tidak boleh memudharatkan dan dimudharatkan" (لا ضرر ولا ضرار). Salah satu pendapatnya yang terkenal adalah tentang pemakaian maslahah sebagai hujjah syari'ah. la mengatakan sekalipun maslahah itu termasuk Mashlahah Mulghah yang oleh para jumhur fuqaha disepakati tidak dapat dipakai sebagai dalil hukum. Namun, dapat dijadikan pedoman dalam menetapkan hukum (hujjah

\footnotetext{
${ }^{4}$ Otje Salman, Filsafat hokum (Bandung: PT. Refika Aditama, 2010) hlm. 8

${ }^{5}$ Abdul Manan, Reformasi hukum Islam, (Jakarta: PT. Raja Grafindo Persada, 2006) hlm.. 271
} 
syari'ah). Bahkan, mashlaha $\underline{h}$ mulgha itu harus didahulukan dari dalil-dalil lain (al-Our'an, al-Hadits dan ijma') jika maslahah menghendakinya. ${ }^{6}$

Menurut Quraish Shihab dalam buku membumikan Al-Qur'an, ada dua sisi ajaran dalam Islam, yaitu sisi nadzariy -meminjam istilah Mahmud syaltut- dan sisi Amaliy. Sisi Nadzariy atau teoritis, berkaitan dengan benak dan jiwa sehingga ia harus dipahami sekaligus diyakini. Ini menjadikan sisi bersifat ke "dalam" dan bukan ke "luar". Apabila sumber dan interpretasi ajaran ini dipastikan kebenarannya, maka ia dinamai 'Aqidah. Sisi amaliy, adalah yang berkaitan dengan pengamalan dalam dunia nyata, yang dinamakan syari'ah.?

Kemudian Quraish Shihab menyimpulkan bahwa akidah adalah sendi utama. Karena itu syari'ah sesekali dapat tidak dilaksanakan asal akidah tetap dipegang teguh, karena akidah berkaitan dengan sisi "dalam" manusia. Menyangkut pelaksanaannya ('amaliy), dapat digarisbawahi bahwa jangankan bagi pihak lain, bagi penganutnya

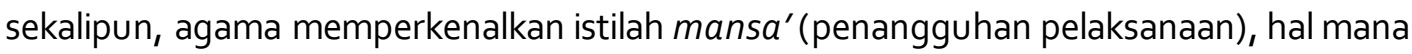
ditempuh apabila pelaksanaannya dihadang oleh kemaslahatan yang lebih besar. ${ }^{8}$

Manusia sebagai khalifatullah fil 'Ardh telah dibekali oleh Allah SWT dengan Akal dan Oalbu, dimana dengan kedua hal ini manusia dapat mengetahui baik (Maslahat) dan buruk (Mafsadat) bagi dirinya dan bagi semuanya.

Walaupun ada pandangan bahwa manusia adalah mahluk sosial, atau Zoon Politicon yang selalu berkelompok, namun dalam hal keberagaman lebih khusus lagi syari'at maka manusia pada akhirnya akan mepraktekkan syari'at secara individual tergantung keimanan masing-masing.

Dalam hal amaliyah, manusia akan selalu cenderung untuk melakukan hal-hal yang dapat mendatangkan kemashlahatan, baik bagi dirinya sendiri maupun bagi semuanya. Dalam tindakan mencapai kemashlahatan ini adakalanya seorang manusia mengalami sebuah kasus yang sama dengan kasus yang dialami oleh orang lain, ada juga yang tidak. Analisia setiap manusia dengan latar belakang kehidupan yang berbeda terhadap kemaslahatan akan menghasilkan versi kemaslahatan yang berbeda pula. Maka terkadang timbul sebuah problem pertentangan kemashlahatan antara manusia dengan yang lainnya.

Manusia secara individu diberi kebebasan dalam menentukan sikap keberagamaannya (syari'atnya). Al-Qur'an pun selalu menuntut kepada manusia disetiap waktu dan tempat untuk menafsirkan ayat-ayatnya sesuai dengan situasi dan kondisi orang yang manafsirkannya.

Pada akhirnya hasil dari penafsiran manusia terhadap al-Qur'an dan Hadits tadi akan diamalkan oleh individu itu sendiri dan dipertanggung jawabkan dihadapan Allah SWT secara individual juga.

\footnotetext{
${ }^{6} \mathrm{Ibid}$. hlm. 286

${ }^{7}$ Quraish Shihab, Membumikan Al-Qur'an, (Bandung: PT. Mizan Pustaka, 2009) hlm. 344

${ }^{8}$ Ibid.
} 


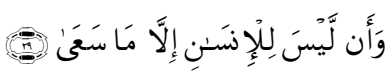

"dan bahwasanya seorang manusia tiada memperoleh selain apa yang telah diusahakannya" (O.S. Al-Najm : 39) ${ }^{9}$

Kontruksi syari'ah pada abad II Hijriyah. dibangun atas karya individual para ahli hukum lebih awal yangh hidup di sejumlah pusat Islam: Madinah dan Makkah, Bashrah dan Kufah, Damaskus dan Mesir ${ }^{10}$. Kemudian diikuti oleh murid-muridnya, lalu dianggap sebagai pendapat yang paling kuat di daerah atau kota tertentu ${ }^{11}$. Hal tersebut menunjukkan bahwa peranan interpretasi terhadap sumber hukum Islam oleh manusia secara individual sangat berharga bagi perkembangan hukum Islam dewasa ini.

Di Indonesia, kebebasan dalam menafsirkan teks-teks keagamaan ini dijamin oleh Negara dengan dituangkannya dalam konstitusi, yaitu pasal 29 ayat 2 yang berbunyi "Negara menjamin kemerdekaan tiap-tiap penduduk untuk memeluk agamanya masingmasing dan untuk beribadat menurut agama dan kepercayaannya itu".

Penulis berkesimpulan bahwa kalimat "beribadat menurut agama dan kepercayaannya itu" lebih jauh lagi tafsir dari kata "kepercayaan" adalah interpretasi seseorang terhadap teks-teks keagamaan yang dia yakini kebenarannya secara individual. Oleh karena itu tidak berhak orang lain menyalahkan pengamalan keagamaan kepada seseorang yang mengamalkan sebuah perbuatan sesuai dengan kemaslahatannya dari hasil pemikirannya terhadap teks-teks keagamaan.

Namun pada kenyataannya, banyak orang dan ormas-ormas Islam yang saling menyalahkan praktek keagamaan yang diamalkan oleh seseorang atau ormas lain di luar pemikiran dari dirinya atau ormasnya. Hal inilah yang kemudian menjadikan stigma di masyarakat bahwa perbedaan itu pada saat ini tidak menjadi rahmat. Padahal jelas-jelas Nabi Muhammad SAW telah bersabda bahwa perbedaan di tengah-tengah umatku adalah rahmat.

Dalam praktek, konsep kebebasan pengamalan syari'at, terutama dalam wilayah moral, kerap disanggah dan ditolak. karena itu, soal kebebasan ini perlu ditelaah kembali, terutama dari sudut pandang Islam. Tulisan ini bertujuan untuk memaparkan proses epistemologis kemaslahatan individu dapat dijadikan kemaslahatan yang umum serta landasan hukum yang digunakan dalam proses tersebut.

\section{Metode Penelitian}

Metode penelitian yang digunakan adalah metode filosofis deskriptif, sedangkan dalam penghimpunan data, sumber data yang digunakan adalah kitab-kitab karya ulama dan para pakar ushul fiqh yang berhubungan dengan Tujuan Hukum Islam, Mashlahah, Qaidah Fiqh dan Qaidah Ushul Fiqh.

\footnotetext{
${ }^{9}$ Departemen Agama, Al-Qur'an dan Terjemahannya, (Jakarta: Gema Risalah Press, 1992) hlm. 874

${ }^{10}$ A bdullah Ahmed An-Na'im, Dekontruksi Syari'ah, (Yogyakarta: LKis Grup, 2011), hlm. 28

${ }^{11}$ A. Qodri Azizy, Reformasi Bermadzhab, (Jakarta: Teraju, cetakan ke-5, 2006) hlm. 17
} 


\section{Hasil dan Pembahasan (Maslahat Perseorangan Dalam Penggalian Hukum Islam)}

Dalam kenyataannya, apa yang diyakini sebagai suatu kebenaran tidak mudah untuk diubah. Demikian halnya ajaran-ajaran agama, baik yang tersimpan dalam khazanah tulisan keagamaan maupun yang terpelihara ddalam tradisi. Sementara itu, kehidupan modern membuka banyak kemungkinan perubahan dan tantangan pembaruan, sehingga kadang-kadang orang merasakan kesulitan besar dalam mempertahankan tradisi dan agama dengan sekaligus menjadi modern. Membiarkan orang dalam kesulitan seperti itu merupakan suatu tindakan tidak bijaksana, selain dapat sangat membahayakan karena agama bisa jadi akan ditinggalkan demi kemodernan. Sementara kemodernan sendiri membawa banyak hal yang tidak baik dan benar. Manusia modern memerlukan agama atau sumber nilai untuk mengurangi dampak buruk modernitas. $^{12}$

Kenyataan yang tidak bisa dibantah adalah bahwa pemahaman manusia terikat zamannya. Karena itu, pemahaman para ulama terdahulu terhadap kitab suci tidak dapat lepas dari keadaan yang melingkupi mereka. Keadaan itu berubah dan banyak hal dari nilai-nilai yang berlaku pada saat mereka memahami kitab suci sekarang sudah tidak berlaku lagi, terutama yang berkenaan dengan cara hidup dan bermasyarakat. Memang ada banyak prinsip yang masih terus berlaku dan tetap dipertahankan dalam segala tempat dan waktu, seperti keadilan, penghormatan pada kemanusiaan dan kebebasan individu untuk menyerru Tuhan, namun tidak jarang juga yang berubah. Misalnya, pandangan hidup yang memberikan tekanan pada keakhiratan pernah sedemikian penting dan menjadi pegangan banyak orang, tetapi kemudian datang kritikaan terhadap pandangan seperti ini dan akhirnya banyak orang yang meninggalkannya. Sudah barang tentu, pemahaman yang dilakukan orang dengan pandangan dunia seperti itu akan sangat jauh berbeda dengan pemahaman orang yang memberikan perhatian besar pada kehidupan masa kini dan di dunia ini. ${ }^{13}$

Juga tidak dapat ditolak bahwa agama yang disakralkan akan menyebabkan kemandegan dalam penghayatan kehidupan keagamaan sendiri. Kesakralan menghalangi orang untuk memikirkan agama, padahal ajaran agama dirumuskan pada masa lalu oleh orang-orang yang hidup dengan persoalan-persoalan yang khas dengan masa itu. Agama semestinya berfungsi memberikan tuntunan kepada para pemeluknya dalam menghadapi persoalan-persoalan kehidupan, bukan menjadi beban yang memberatkan pemeluknya atau belenggu yang membatasi kreativitas dan daya hidupnya. Mengembalikan agama pada fungsi pokoknya sebagai pemberi arahan hidup ini menghendaki perubahan terhaadap rumusan ajarannya.

\footnotetext{
${ }^{12}$ Machasin, islam Dinamis Islam Harmonis, (Yogyakarta: Lkis, 2011), hlm. 15

${ }^{13}$ Ibid. hlm. 16
} 
Sementara itu, perubahan bagi sesuatu yang sedemikian berarti dalam kehidupan bukan merupakan sesuatu yang mudah. Diperlukan dasar pembenaran yang kuat, dan dukungan kitab suci merupakan satu dukungan yang kuat. Untuk itu diperlukan pembacaan kembali kitab suci, sehingga ditemukan pengertian yang sesuai dengan kebutuhan kehidupan yang berubah dari waktu ke waktu.

Dalam buku Islamic Futures, Ziauddin Sardar berkata: ${ }^{14}$

"Bahwa syari'ah merupakan metodologi. Bahwa esensinya syari'ah bukanlah ketentuan hukum, Syari'ah merupakan etika dan metodologi. la merupakan metode untuk melakukan pemahaman ulang terhadap Islam, metode untuk mengkaji ulang pemikiran secara terus menerus. Jika dikatakan bahwa Al-Qur'an bersifat abadi, maka keharusan untuk melakukan penggalian makna teks AlQur'an itu akan terus berlaku hingga akhir zaman. Setiap generasi harus berusaha memahami teks-teks keagamaan dan melakukan pemikiran ulang sesuai petunjuk pengetahuan yang mereka kuasai. Pengetahuan bukanlah sesuatu yang bersifat statis, pengetahuan akan terus berkembang. Apa yang kita ketahui pada masa kini, misalnya, tentu sangat jauh berbeda dengan apa yang diketahui oleh Muslim pada masa dahulu. Permasalahan-permasalahan yang kita hadapi sekarang sangat jauh berbeda dengan permasalahan-permasalahan yang dihadapi Muslim periode terdahulu. Dan permasalahan yang paling penting dalam setiap masyarakat Muslim membutuhkan penanganan yang berbeda. Dan seandainya kita berupaya memahami syari'ah secara benar, tentu kita tidak dapat mentransformassikan syari'ah dalam bentuk yang kaku dan jumud (beku), dalam pengertian bahwa semua jawaban permasalahan telah disediakan. Karena setiap jawaban harus didiskusikan ulang."

Demikian juga dengan Hukum Islam (figh), ketika disakralkan akan terjadi kemandegan dan terbelenggunya kreativitas manusia dalam mengatur kehidupannya, baik hubungannya dengan Tuhan, maupun hubungannya dengan sesama makhluk ciptaan-Nya. Mengingat bahwa kemaslahatan setiap manusia itu berbeda karena dipengaruhi oleh keadaan dan kondisi lingkungannya, maka fiqh dituntut untuk selalu berkembang sejalan dengan keadaan dan kondisi lingkungan yang berubah. Pintu ijtihad adalah jalan yang mengantarkan manusia kepada perkembangan tersebut.

Kemaslahatan dalam arti sebuah tindakan untuk mengambil sebuah manfaat (mashlahah) dan menghindarkan diri dari kerusakan (mafsadat) dengan cara penggunaan akal secara optimal disertai dengan pengamatan terhadap kondisi lingkungan tanpa meninggalkan nash-nash petunjuk dalam al-Qur'an maupun Hadits pada masa sekarang akan lebih mampu menjawab tuntutan-tuntutan persoalan kontemporer.

${ }^{14}$ Ziauddin Sardar, Islam Tanpa Syariat, ed. Abdul Mu'ti dan Ahmad Najib Burhani, (Jakarta: Grafindo Khazanah Ilmu, 2005), hlm. 42 


\section{Kebebasan Melakukan ljtihad Oleh Setiap Orang}

Ciri dominan dalam mengamati sebab kemunduran umat Islam adalah tertutupnya pintu ijtihad. Walaupun dalam sejarah tidak ditemukan data otentik tentang ulama yang berpendapat bahwa ijtihad telah ditutup. ${ }^{15}$

Pintu ljtihad dalam Islam terbuka bagi siapa saja yang memiliki kredibilitas, dan dalam ruang lingkup ijtihad yang diperbolehkan dalam syara'. Ijtihad adalah proses pengambilan hukum syara dari dalil-dalilnya yang terperinci. Sumber tasyri' dalam Islam adalah Allah SWT, yang telah menurunkan hukum-hukum dan beberapa syari'at dalam Al-Qur'an dan mewahyukan kepada Nabi-Nya dengan merinci dan menjelaskan garis besarnya dan membatasi kemutlakannya. ${ }^{16} \mathrm{Apabila}$ pintu ijtihad dalam Islam terbuka, maka kebebasan di dalamnya merupakan hak bagi seluruh manusia dengan syarat harus Islam, beriman dan mukallaf (baligh dan berakal), karena ijtihad adalah pengambilan hukum dari dalil syar'inya, dan pokok dalilnya adalah AI-Qur'an dan Sunnah. ${ }^{17}$

ljtihad adalah upaya maksimal seorang mujtahid dalam menyusun dan merumuskan ketentuan hukum syari'at atau fiqh yang bersumber dari Al-Qur'an dan Hadits. Syarat ijtihad terdiri dari dua syarat: pertama, mujtahid harus mengerahkan kemampuannya secara maksimal sehingga ia tidak main-main dalam menyusun dan merumuskan ketentuan hukum fiqh. Mujtahid harus mempertimbangkan secara komprehensif dalam mengeluarkan ketentuan hukum dari nas Al-Qur'an dan Hadits, disamping aspek budaya yang melingkupinya. Kedua, mujtahid berusaha maksimal untuk menyusun dan merumuskan ketentuan hukum fiqh dan tidak masuk paada ranah yang ubudiyah, ia hanya boleh masuk berijtihad padah ranah muamalah atau hal-hal yang bisa dirasionalkan (reasonable). ${ }^{18}$

Tingkatan mujtahid meliputi tiga tingkatan: pertama, Mujtahid fi Al-Madzhab, adalah seorang mujtahid yang dalam melakukan ijtihadnya mengikuti teori ijtihad yang sudah dibangun oleh salah satu imam madzhab sebelumnya, sedangkan produk hukumnya boleh berbeda dengan hasil ijtihad hukum para pendahulunya. Untuk membangun paradigm ijtihad ini, seorang mujtahid menguasai hukum-hukum dan dalil-dalil yang digunakan oleh madzhabnya, sehingga produk hukumnya tetap berada dalam spirit sumber aslinya walaupun berbeda dengan hasil-hasil karya mujtahid pada madzhab yang diikutinya. Kedua, mujtahid fi Al-Mas'alah adalah seorang mujtahid yang melakukan ijtihad dengan bekal pengetahuan yang memadai dalam bidang hukum yang akan dipecahkan walaupun tidak terlalu menguasai pada aspek-aspek hukum lainnya. Produk hukumnya juga dapat berbeda dengan hasil-hasil karya ulama fiqh madzhab sebelumnya. Ketiga, Mujtahid Al-Mutlaq adalah seorang yang memiliki kemampuan

${ }^{15}$ Jaih Mubarok, Sejarah dan Perkembangan Hukum Islam, (Bandung: Remaja Rosda Karya, 2000) HIm. 140

${ }^{16}$ Wahbah Az-Zuhaili, Kebebasan dalam Islam, (Jakarta: Pustaka Al-Kautsar, 2005), hlm. 264

${ }^{17} \mathrm{lbid}$. hlm. 265

${ }^{18}$ Moh. Dahlan. Paradigma Ushul Fiqh Multikultural Gus Dur, (Yogyakarta: Kaukaba, 2013), hlm. 67 
untuk menyusun dan merumuskan teori ijtihad yang baru dan produk hukum-hukum fiqh yang baru. Sebagai konsekuensinya, mujtahid ini harus memiliki bekal keilmuan yang memadai dan komprehensif, yaitu bidang keilmuan Al-Qur'an, Sunnah, ijma', teori jam'u, tarjih, dan ta'arud, serta ilmu-ilmu alat seperti bahasa Arab, petunjuk-petunjuk lafadz dan unsur sastranya. ${ }^{19}$

Hasil-hasil karya mujtahid mutlak tentunya memiliki keunggulan tersendiri dari hasil-hasil karya mujtahid di bawahnya, sebab mujtahid mutlak memiliki bekal keilmuan dan penguasaan yang memadai dan komprehensif dalam bidang teori ijtihad dan penguasaan hukum-hukum fiqh, sehingga produk hukumnya memiliki kekuatan yang lebih unggul.

ljtihad merupakan sebuah spesialisasi yang membutuhkan kepiawaian atau naluri ijtihad yang dapat diketahui melalui pengalaman dan berkembang melalui latihan, diketahui melalui ketentraman umat Islam terhadap keselamatan pendapat, menjaga ruh syari'at, mengetahui kaidah-kaidah syari'at baik yang bersifat menyeluruh ( $k u l l i)$ ataupun sebagian (juz'i), ini adalah yang harus dipenuhi dalam ijtihad. ${ }^{20}$

Menurut Wahbah Az-Zuhaili, orang yang melakukan ijtihad pada masa sekarang kebanyakan pendapatnya sama dengan para mujtahid yang dahulu, ia hanya sebatas melakukan tarjih (pemilahan). Tapi, meskipun demikian hal ini juga termasuk ijtihad, karena tarjih adalah ijtihad. ${ }^{21}$

Menurut Ziauddin Sardar salah satu hal yang merupakan sebab mengapa orang tidak melakukan kajian (ijtihad) adalah adanya anggapan bahwa syari'ah itu suci, syari'ah itu tidak dapat diubah. Padahal sesungguhnya Al-Qur'an sajalah yang tidak dapat diubah. Syari'ah sebagai interpretasi atas Al-Our'an sebenarnya bisa diubah dan dia terbuka untuk dikaji ulang karena syari'ah sesungguhnya bentuk pemahaman yang dilakukan terhadap teks suci. Kemudian, umat perlu melakukan dan mengkaji kembali ajaran agama itu. Orang-orang awam sebenarnya boleh melakukan pengkajian dan pemikiran kembali terhadap pemikiran-pemikiran pada masa lalu yang dilakukan oleh para ulama. Semua orang punya otoritas, tetapi saya kira mereka perlu memahami dan mengkaji pemikiran itu secara mendalam. Karena itu, kaum terpelajarlah yang sebenarnya memiliki otoritas untuk melakukan kajian dan penafsiran kembaliterhadap pemikiranpemikiran pada masa lalu. ${ }^{22}$ Namun pendapat Ziauddin Sardar ini menurut penulis terlalu berani dengan tidak mensyaratkan siapa saja orangnya yang berhak untuk melakukan pengkajian dan pemikiran kembali dalam Islam ini, padahal seharusnya rethinking Islam hanya dapat dilakukan oleh orang-orang yang mempunyai kerangka metode berpikir yang jelas dan didukung dengan pemahaman terhadap keilmuan Islam lainnya.

\footnotetext{
${ }^{19} \mathrm{lbid}$. hlm. 68

${ }^{20}$ Wahbah Az-Zuhaili, Kebebasan dalam Islam... hlm. 265

${ }^{21} \mathrm{Ibid}$. hlm. 268

${ }^{22}$ Ziauddin Sardar, Islam Tanpa Syariat.. hlm. 52
} 
Adapun hal-hal baru yang menyangkut permasalahan kehidupan modern seperti permasalahan sarana angkutan darat, laut dan udara serta masalah ekonomi modern seperti perbankan Islam, merupakan ladang subur bagi ijtihad. Kebebasan dalam hal ini merupakan hak bagi mereka yang memiliki kredibilitas. ${ }^{23}$

Dapat disimpulkan bahwa pintu ijtihad selalu terbuka bagi orang-orang yang mempunyai kemampuan untuk berijtihad, baik dalam kategori mujtahid mutlak, mujtahid fi al-madzhab, mujtahid tarjih, atau mujtahid fatwa.

\section{Pengaruh Maslahat Perseorangan Terhadap Metode ljtihad}

Pada masa-masa awal terbentuknya hukum Islam (ilmu fiqh), dikenal ada dua kubu pengembang pemikiran hukum Islam, yaitu kubu Irak dan kubu Hijaz. Tokoh utama kubu Irak adalah Imam Abu Hanifah, dan tokoh utama kubu Hijaz adalah Imam Malik. Para ulama kubu Irak dikenal dengan sebutan ahl al-ra'y; sedangkan para ulama kubu Hijaz dikenal sebagai ahl al-hadits. ${ }^{24}$

Sebutan ahl al-ra'y bagi madzhab Irak terkait erat dengan pola pemikiran hukum yang mereka kembangkan yakni volume penggunaan rasio lebih besar dibandingkan volume penggunaan hadits (sebagai salah satu sumber syari'ah). Ini bukan berarti mereka tidak mengakui keabsahan hadits atau sama sekali tidak menggunakan hadits sebagai sumber hukum, namun lebih disebabkan penggunaannya yang sangat terbatas. Aliran ahl al-ra'y lebih diterima di Irak karena sesuai dengan mentalitas bangsa Parsi yang pada waktu itu telah memiliki tingkat intelektual dan kebudayaan yang lebih maju, terutama di kota-kota seperti Baghdad dan Kuffah. Sebaliknya, sebutan ahl al-hadits yang disandang para ulama madzhab Hijaz, dihubungkan dengan pola pengembangaan pemikiran hukum mereka, sesuai dengan situasi lingkungannya yang penggunaan hadits lebih besar dibandingkan penggunaan rasio (dalam hal ini qiyas). Ini juga tidak berarti mereka menolak sama sekali penggunaan rasio, namun lebih dikarenakan penggunaannya yang cenderung terbatas. Aliran ini diterima di hijaz karena sejalan dengan mentalitas bangsa Arab saat itu yang lebih tradisional dan suasana hidup yang lebih konservatif, termasuk di kota-kota mekah dan madinah. Disamping itu, tradisi kehidupan di Hijaz telah dibentuk oleh atsar baik berupa hadits maupun praktik para sahabat Rasulullah, singkatnya atsar telah melekat erat dalam kehidupan masyarakat $\mathrm{Hijaz}^{25}$

Kalangan ahl al-ra'y sesungguhnya tidak hanya menggunakan qiyas yang merupakan bentuk penggunaan rasio dengan cara analogi ilmiah secara ketat, tetapi mereka juga menggunakan analogi yang longgar dan lebih luas. Dalam hubungan inilah lahirnya konsep istihsan. ${ }^{26}$

\footnotetext{
${ }^{23}$ Wahbah Az-Zuhaili, Kebebasan dalam Islam ... hlm. 265

${ }^{24}$ Hasbi Umar. Nalar Figh Kontemporer (Jakarta: Gaung Persada Press, 2007), hlm. 107

${ }^{25} \mathrm{lbid}$. hlm. 107-108

${ }^{26}$ Ibid.
} 
Madzhab Hanafi menjelaskan bahwa istihsan wajib dilakukan karena illat-nya ditetapkan menurut atsar (fakta yang efektif). Atsar yang lemah hanya sampai pada tingkat qiyas, sedangkan atsar yang kuat itulah yang sampai pada tingkat istihsan. Dengan demikian, istihsan adalah cara menjalankan fungsi salah satu qiyas yang terkuat. $^{27}$

Sejalan dengan itu, Al-Sarakhshi membagi dua macam qiyas. Yang pertama adalah qiyas jali dengan illat yang jelas tetapi kurang efektif, dan kurang sesuai dengan tuntutan sosial, yang sering disebut juga dengan qiyas biasa, yaitu qiyas yang digunakan oleh Madzhab Syafi'i. Sedangkan yang kedua adalah qiyas khafi, yang illat-nya kurang jelas namun sangat efektif pengaruhnya pada pemanfaatan (kemaslahatan) ketimbang yang pertama, dan sangat kuat relevansinya dengan tuntutan sosial. Qiyas khafi inilah yang disebut istihsan atau qiyas mustahsin. Itulah sebabnya mengapa istihsan lebih utama dari pada qiyas. Al-sarakhsi menambahkan bahwa istihsan itu berarti meninggalkan qiyas biasa untuk menerapkan apa yang sesuai dengan manfaat yang dibutuhkan manusia. ${ }^{28}$

Dari pengertian di atas, istihsan dalam versi Madzhab Hanafi dimaksudkan sebagai cara untuk menetapkaan salah satu di antara dua alternatif hukum yang dianggap lebih dekat kepada kebutuhan manusia atau meninggalkan kesulitan untuk kemudahan.

Hasbi Umar mengungkapkan ada dua bentuk istihsan, pertama, Istihsan bi al-Nas yaitu istihsan yang bersandarkan pada nas lain yang menghendaki tidak diberlakukannya dalil yang pertama. Dalil yang pertama bersifat khusus, sedangkan dalil yang kedua bersifat umum, jadi lebih bersifat pengecualian. Kedua, Istihsan bi al-mashlahah, yaitu istihsan yang didasarkan pada maslahat dalam berbagai tingkatannya. Adakalanya maslahat tersebut masuk dalam level dharuriyah dan adakalanya masuk dlam level hajiyah. $^{29}$

Sudah dapat dipastikan bahwa tujuan teori istihsan adalah untuk memperoleh kemaslahatan. Hanya saja kemaslahatan yang dimaksud adakalanya ditentukan oleh nas dan adakalanya tidak. Dalam hal yang disebutkan terakhir, peranan mujtahid sangatlah penting khususnya untuk mengidentifikasi jenis kemaslahatan sekaligus memperhatikan tingkat maslahatnya.

Muhammad Syahrur sependapat dengan Al-Syatibi mengenai pentingnya seorang mujtahid selalu melihat realitas masyarakat dalam proses ijtihad, secara eksplisit AlSyatibi menekankan pentingnya para pakar ilmu ushul fiqh untuk menjadikan ilmu ushul fiqh sebagai ilmu yang peduli dengan realitas kemanusiaan. Realitas empirik kemanusiaan merupakan sebab hukum yang harus dilihat bila seorang mujtahid akan menggali hukum. ${ }^{30}$

${ }^{27}$ Hamka Haq. 2007. Al-Syatibi: Aspek Teologis Konsep Mashlahah dalam kitab Al-Muwafaqat, (Jakarta: Erlangga. 2007) hlm. 245

${ }^{28} \mathrm{Ibid}$.

${ }^{29}$ Hasbi Umar, Nalar Fiqh... hlm. 111

${ }^{30}$ Muhyar Fanani, Fiqh Madani: Kontruksi Hukum Islam di Dunia Modern, (Yogyakarta: Lkis, 2010) hlm. 175-176 
Dapat dilihat adanya hubungan yang mempengaruhi antara kemaslahatan dengan metode ijtihad (dalam hal ini adalah Qiyas dan Istihsan). Qiyas yang selama ini menjadi ciri khas madzhab syafi'i dengan karakter deduksinya dihadapkan dengan istihsan yang menjadi cirri khas madzhab Hanafi dengan karakter induksinya, karena pengaruh dari kemaslahatan manusia sebagai mukallaf sebagai objek keduanya.

Hasbi Ash-Shiddieqy berpendapat bahwa upaya memecahkan masalah hukum baru tidak cukup hanya bertumpu pada qiyas semata, yang selama ini dipakai sebagai satu-satunya pola ijtihad madzhab syafi'i. Hal ini lebih dikarenakan sifat eksklusifnya tidak mampu lagi memenuhi tuntutan perubahan zaman. Jika ia dipaksakan sebagai pilihan bagi metode penemuan hukum Islam, maka akan terdapat kemaslahatan manusia yang terabaikan. Maka semua metode penemuan hukum yang ada, yang memungkinkan untuk melahirkan satu rumusan hukum yang berbasis mashlahah dimungkinkan untuk diaplikasikan sebagai metode istimbath hukum. ${ }^{31}$

Antara istihsan dengang mashlahah memiliki perbedaan yang sangat tipis. Istihsan berhubungan dengan masalah-masalah hukum fiqh yang pada awalnya mengikuti ketentuan qiyas kemudian istihsan menggantinya sebagai paradigma ijtihad untuk mencetuskan keputusan hukum fiqh, sedangkan mashlahah sejak dari awal mula sudah dalil ijtihad yang digunakan untuk memecahkan permasalahan-permasalahan hukum di dalam ruang lingkupnya. Oleh sebab itu, Moh. Dahlan yang mengutip pendapat Usman menyatakan bahwa salah satu jenis istihsan adalah istihsan dengan parameter mashlaha $\underline{h}$, yaitu istihsan yang dimaksudkan untuk mewujudkan kemaslahatan, sehingga untuk mengukur berlaku atau tidaknya keputusan hukum berdasarkan asas kemashlahatan tersebut. Misalnya, adanya larangan jual beli barang yang tidak ada (bai' al$m a^{\prime} d u m$ ), tetapi dengan adanya tuntutan kemaslahatan yang dibutuhkan oleh segenap umat manusia dan tidak bisa dihindarkan kebutuhan itu, sehingga akad salâm sebagai bentuk bâi' al-ma'dum diperbolehkan berdasarkan dalil istihsan.

Demikian juga Uang Muka dalam Murabahah Fatwa Dewan Syari'ah Nasional (DSN) No.13 yang berlandaskan kaidah mashlahah. Disamping itu, misalnya transaksi jual beli mobil, Bank memberikan pinjaman uang muka untuk membeli mobil, tapi mobilnya baru akan diambil di show room, dan juga credit card dapat dibolehkan karena sangat dibutuhkan di saat ini berdasarkan kaidah "kebutuhan menempati tempatnya darurat".

Sedangkan contoh lainnya adalah shohibul mal mempercayakan mudlarib untuk berbisnis makanan siap saji, tetapi dalam perjalanan pelaksanaan kontrak mudlarabah kemudian mudlarib beralih kepada bisnis pakaian jadi. Dalam kasus ini ada penyimpangan dari penggunaan dana yang dikehendaki oleh shohibul mal kepada bisnis lainnya, tetapi dengan bisnis tersebut mudlarib mendapatkan untuk yang lebih besar. Oleh sebab itu, mudlarib berhak mendapatkan ujrah (fee) atas dasar istihsan. Sedangkan menurut

${ }^{11}$ Mahsun fuad, Hukum Islam Indonesia dari Nalar Partisipatoris Hingga Emansipatoris, (Yogyakarta: Lkis, 2005) hlm. 202 
ketentuan umum, mudlarib tidak berhak, karena adanya penyimpangan penggunaan dana tersebut. ${ }^{32}$

Dalam kasus muamalah di atas dapat disimpulkan bahwa mashalahah perseorangan dapat dijadikan illat hukum dari setiap permasalahan yang ada, seperti dalam contoh kasus mudlârabah di atas. Mudlarib yang sudah keluar dari akad semula dengan shohibul maal tetap mendapatkan ujrah atas hasil kerjanya yang telah meberikan keuntungan kepada shohibul maal. Padahal hukum asal menyalahi akad adalah haram, maka hasil mudlarabahnya pun haram. Tetapi karena tercapainya tujuan shohibul maal berupa keuntungan yang besar dan melihat kemaslahatan seorang mudlarib yang telah berusaha tadi, maka berdasarkan istihsan mudlarib tetap mendapatkan hak ujrahnya.

Dalam penggalian hukum yang akan berlaku umum mashlahah perseorangan mempunyai ketentuan, yaitu seperti yang diterangkan oleh Yusuf Qaradhawi:

Tabel 1 Mashlahah perseorangan menurut Yusuf al-Oaradhawi ${ }^{33}$

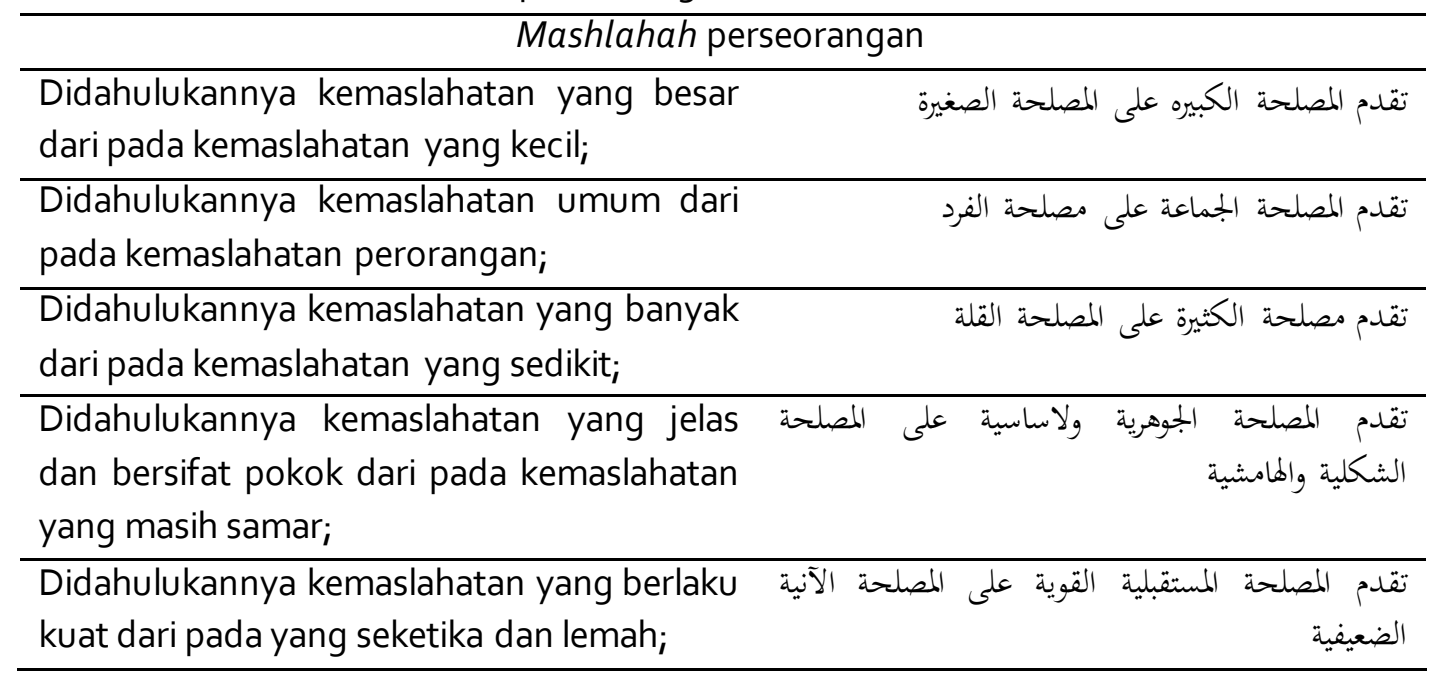

Dari keterangan di atas dapat disimpulkan bahwa mashlahah perseorangan ketika bertentangan dengan kemaslahatan umum harus dikesampingkan, namun bukan berarti menghapus begitu saja kemaslahatan perseorangan tersebut, karena dalam kemaslahatan umum itu juga terdapat kemaslahatan-kemaslahatan perseorangan.

Mashlahah perseorangan dalam arti kemaslahatan bagi kelompok di luar mainstream juga dapat ditemukan dalam Fiqh al-Aqâlliyat (Fiqh Minoritas) yang konsep oleh Yusuf Oaradhawi. Konsep metodologi ushul fiqh dari figh ini lebih menekankan kepada prinsip-prinsip umum dan nilai-nilai universal al-Qur'an sebagai dasar utama penentuan hukum dalam masalah yang dihadapinya, Sunnah yang biasanya merupakan respon terhadap suatu kejadian khusus dan pada waktu tertentu harus dipahami sejalan dengan

\footnotetext{
${ }^{32}$ Moh. Dahlan, Paradigma Ushul Fiqh..., hlm. 109-110

${ }^{33}$ Yusuf Al-Qaradhawi, Hasan Al-Nadwi Dalam Kenangan Yusuf Al-Qaradhawi (Jakarta: Kafila Press, 2000). HIm. 28
} 
prinsip-prinsip umum al-Qur'an, ljma yang merupakan kesepakatan ulama pada kurun waktu tertentu, di tempat tertentu, dan untuk peristiwa tertentu, harus juga dipahami sejalan dengan maqâshid al-syari'a h yang prinsip-prinsip umumnya terkandung dalam alQur'an. Manakala ijma masa lalu telah dirasa tidak sesuai dengan konteks saat ini, ia tidak perlu diikuti karena mengikuti kaidah perubahan hukum itu berdasarkan masa dan tempat. Demikian juga qiyas, ia tidak boleh melahirkan hukum yang bertentangan dengan prinsip-prinsip umum al-Qur'an. ${ }^{34}$

Di samping sumber-sumber di atas, fiqh al-aqâlliyat juga menggunakan beberapa sumber atau dalil lainnya yang diperselisihkan oleh para fuqoha, seperti istishlah, istihsan, sad al-dhâra'i, syar'man qablana, al-'urf, istishab, qawl alshâhabi, dan lain sebagainya. ${ }^{35}$

Dalam aplikasinya piranti-piranti ushul figh ini semuanya digunakan untuk kemudian produk-produk hukumnya dikoleksi menjadi opsi-opsi yang akan dipilih berdasarkan tingkat kesesuaiannya dengan kemaslahatan yang diharapkan dan tingkat kemudahan dalam mengaplikasikannya.

Kemaslahatan perseorangan juga dapat didudukkan sebagai tujuan dari hukum Islam itu sendiri, hal ini dapat dikonsepsikan melalui proses dialektika antara konsep alistigra al-ma'nawi yang dikembangankan oleh al-Syatibi, konsep kiri Islam yang dikembangkan oleh Hassan Hanafi, dan Fiqh al-Aqâlliyat yang dikembangkan oleh Yusuf Qaradhawi. Ketiga konsep ini bertemu pada satu benang merah yakni bertujuan agar adanya opsi-opsi hukum Islam dalam fiqh.

Konsep al-istiqra al-ma'nawi dari al-Syatibi adalah suatu metode pengambilan hukum yang bukan hanya dilakukan dengan satu dalil tertentu, tetapi dengan sejumlah dalil yang digabungkan antara satu saama lain yang mengandung aspek dan tujuan berbeda, sehingga terbentuklah suatu perkara hukum berdasarkan gabungan dalil-dalil tersebut. Al-Syatibi melanjutkan bahwa para pemikir hukum Islam tidak boleh menetapkan tujuan al-Syari' hanya berdasarkan dalil tertentu dan dengan cara tertentu saja, tetapi untuk menemukannya haruslah dengan meneliti semua dalil yang relevan, baik yang sifatnya zhahir, muthlaq, muqoyyad, kulliyah, atau juz'iyah dalam berbagai variasi dalam setiap bab hukum fiqh. Dengan cara ini, kesimpulan hukum akan didapatkan secara pasti atau yakin. ${ }^{36}$

Sedangkan Kiri Islam konsep Hassan Hanafi dalam bidang fiqh mempunyai sebuah keberanian dalam membuat keputusan hukum berdasarkan realitas dan kemaslahatan umum, bercermin pada Malikiyah, penggunaan akal secara optimal dalam interpretasi teks yang bercermin kepada Hanafiyah, pemaduan rasio dan realitas bercermin kepada Syafi'iyah, dan komitmen terhadap teks bercermin pada Hanbaliyah. Hassan Hanafi

\footnotetext{
${ }^{34}$ Ahmad Imam Mawardi, Fiqh Minoritas: Fiqh al-Aqalliyat dan evolusi Maqashid al-Syari'ah dari konsep ke pendekatan, (Yogyakarta: Lkis, 2010) Hal. 140-141

${ }^{35} \mathrm{Ibid}$. hlm. 141

${ }^{36}$ Duski Ibrahim, Metode Penetapan Hukum Islam, Membongkar Konsep Al-Istiqra Al-Ma'nawi AlSyatibi, (Jogjakarta: Ar-Ruzz Media, 2008) hlm.162
} 
berpendapat bahwa teks adalah refleksi atas realitas, Kiri Islam menerima apa yang terdapat di dalam al-Qur'an dan Sunnah yang sahih karena syari'at pada dasarnya berdiri atas landasan kemaslahatan. Menerima al-Qur'an dan Sunnah yang sahih berarti menerima prinsip-prinsip kemaslahatan itu. ${ }^{37}$ Dari sinilah terlihat kekayaan epistemologi dalam Kiri Islam yang mengakomodasi seluruh pemikiran 4 madzhab yang ada dalam kajian hukum Islam, namun yang disayangkan adalah Kiri Islam menafikan hal yang tidak bisa dijangkau oleh akal (unrasionable) seperti tasawwuf.

Gabungan ketiga metode tadi (Figh al-Aqalliyat, Kiri Islam, dan al-istigra alma'nawi) akan dapat menghasilkan opsi-opsi hukum fiqh yang kaya wacana karena didukung oleh konstruk epistemologi yang banyak, sehingga seseorang dapat memilih mengambil opsi-opsi yang ada itu untuk diamalkan sesuai dengan kebutuhan (hajat-nya). Namun yang paling penting adalah kekonsistensian seseorang tersebut dalam mengambil opsi-opsi yang ada jangan sampai dijadikan alasan untuk "mendalili amal" yang penuh akan muatan nafsu dan syahwat.

Sebagai contoh penggunaan metode ini adalah pada hukum minuman keras (Khomer), menurut Imam al-Syafi'i berdasarkan qiyas khomer itu haram baik sedikit maupun banyak, namun menurut pandangan Imam Abu Hanifah berdasakan istihsan khomer itu baru haram apabila sang peminum telah mabuk. Apabila peminum tersebut belum mabuk maka khomer diperbolehkan untuk dikonsumsi. Dari sinilah muncul dua opsi hukum dalam khomer yakni haram secara mutlak dan boleh asalkan sang peminum tidak mabuk. Dari dua opsi ini dapat ditarik lebih jauh hukum khomer dijadikan sebagai obat, atau hukum meminum khomer di daerah yang sangat dingin dengan bertujuan menghangatkan badan ( hifdz al-nafs), bagaimana hukum jual beli khomer dalam konteks hifdzal-maal. Dengan tetap melihat pada sebuah kaidah fiqh (اذا ضاق الامر اتسع واذا اتسع الام ضاق). Namun sekali lagi permasalahan yang timbul dalam pengaplikasiannya adalah kejujuran untuk mengakui keadaan dirinya sendiri, dan keluar dari nafsu syahwat sendiri.

Peran illat hukum sangat penting dalam konsep kemashlahatan perseorang yang dijadikan standar bagi kemashlahatan umum. Illat merupakan sebuah sebab adanya suatu hukum. Apabila sekelompok orang mempunyai illat syar'i yang berbeda dengan kelompok orang lain maka hukum fiqh yang berlaku bagi sekelompok orang tersebut harus di bedakan dengan sekelompok orang lainnya yang mempunyai illat syar'i yang berbeda pula. Maka di sini berlaku kaidah fiqh dalam menentukan hukum yang berlaku umum ini الحكم يدور مع العلة وجودا وعدما.

\section{Masalah Taklif Bi Ma La Yuthaq}

Masalah taklifbima la yuthaq (tuntutan atas perbuatan di luar daya manusia) dikaji dalam teologi Islam dan ushul fiqh sehubungan dengan masalah daya dan tanggung

${ }^{37}$ Kazuo Shimogaki, Kiri Islam, Antara Modernisme dan Postmodernisme (Yogyakarta : Lkis, Cet. VIII, 
jawab manusia atas perbuatannya. Pembicaraan tentang masalah ini memang tidak dapat dilepaskan dari dua hal, yakni daya dan tanggung jawab manusia itu. Hampir semua kajian Al-syatibi dala Al-Muwâfaqât yang mengacu kepada kemaslahatan manusia secara universal adalah menjadikan daya dan tanggung jawab manusia sebagai dasar pertimbangan hukum taklif. ${ }^{3}$

Daya manusia jelas merupakan syarat utama berlakunya hukum taklif. Hal itu karena taklif berarti tuntutan yang memberi beban atas manusia sekaligus juga meminta tanggung jawab yang mustahid dapat dipenuhi jika manusia tidak berdaya melakukannya. Al-Syatibi menegaskan bahwa syari'at tidak mungkin memerintahkan sesuatu yang manusia tidak bisa lakukan.

Syari'at akan menilai perbuatan manusia dalam kerangka taklif hanya jika dilakukan dalam tiga keadaan. Yaitu, pertama, berada dalam batas-batas daya jasmani manusia sendiri. Karena itu, segala tindakan yang dapat merusaak jasmani atau mustahil dilakukan, syari'at tidak akan memerintahkannya. Kedua, manusia mempunyai daya mengetahui dan mengerti cara pelaksanaan amal yang diperintahkan. Karena itu, manusia yang sedang tidur, lupa, masih kanak-kanak, atau gila, semuanya bebas dari hukum taklif. Ketiga, amal itu dilakukan atas kesadaran manusia sendiri, atas dasar kesengajaan, dan tidak dipaksa oleh keadaan dan orang lain.

Karena daya manusia menjadi syarat mutlak berlakunya hukum taklif, maka syari'at yang tujuan pokoknya adalah kemaslahatan manusia tidak menghendaki kesulitan (masyaqah) atas manusia. Dalam hal kesulitan ini, Al-Syatibi sangat konsisten menerapkan paham teologi yang menolak taklif bi ma la yuthaq. Al-Syatibi menegaskan keyakinan akan tertolaknya taklif bi ma la yuthaq dalam ushul fiqh. Maksudnya, tidak mungkin berlaku suatu tuntutan yng di dalamnya terdapat kesulitaan yang luar biasa. ${ }^{39}$

\section{Maslahah Perseorangan dalam Pengamalan Hukum Islam}

Hukum taklif, baik menyangkut akidah maupun ibadah, senantiasa mengacu kepada tingkat pemaahaman secara universal. Maksudnya, akidah dan ibadah itu harus dapat dipahami dengan mudah oleh manusia secara umum karena jika syari'at sulit dipahami, maka Allah telah membebani hamba-Nya sesuatu diluar kemampuan orang banyak, padahal dia mustahil berbuat demikian. ${ }^{40}$

Selain mudah dipahami, syari'at juga harus sesuai dengan kebiasaan yang sudah merupakan kondisi umum kehidupan manusia. Hal ini dimaksudkan agar syari'at tiak membawa manusia kepada kesulitan dan tidak pula mengabaikan sama sekali adat kebiasaan yang telah menjadi pilar utama kemaslahatan dunia mereka. Itulah sebabnya Al-Qur'an diturunkan secara bertahap lebih dari dua puluh tahun dan hukum yang

\footnotetext{
${ }^{38}$ Hamka Haq, Al-Syatibi: Aspek Teologis..., hlm. 207

${ }^{39} \mathrm{lbid}$. hal. 209

${ }^{40} \mathrm{lbid}$.
} 
dikandungnya juga berlaku sedikit demi sedikit guna menyesuaikan syari'at dengan perkembangan hidup manusia sehingga manusia tidak merasa terbebani dan tidak menjauhi syari'at. Sebuah kisah tentang 'Umar ibn 'Abdul 'Aziz menarik untuk disimak, yaitu saat ia didesak oleh putranya untuk menerapkan hukum secara serentak. 'Umar berkata, "wahai anakku, janganlah terburu-buru. Sesungguhnya Allah mencela khamar sebanyak dua kali dan mengharamkannya nanti pada yang ketiga kali. Aku khawatir, jika kebenaran diterapkan serentak atas manusia, mereka akan menolaknya serentak pula. ${ }^{41}$ Hal ini sejalan dengan pendapat Hasbi Ash-Shiddieqy tentang Asas Tadarruj, yang berarti bertahap (gradual), artinya pembinaan hukum Islam berjalan setahap demi setahap disesuaikan dengan tahapan perkembangan manusia. ${ }^{42}$

Hamka Haq dalam hal ini tidak membedakan antara kebiasaan manusia (al-'adat) yang sesuai dengan syari'at, dengan kebiasaan yang bertentangan dengan syari'at. Namun penulis artikan bahwa kebiasaan tersebut adalah kebiasaan yang sesuai dengan syari'at, dalam arti sebuah kebiasaan yang lahir akibat interpretasi manusia terhadap alQur'an dan Sunnah dan berlaku umum di masyarakat.

Hukum Islam tampil bersifat ramah dan tidak secara drastis merombak kehidupan sehari-hari manusia. Hal ini ditandai dengan berlakunya hukum secara bertahap sehingga hukum itu akan berlaku karena kondisi sosial turut mendukungnya. Hal ini menunjukkan bahwa syari'at selalu menjauhkan manusia dari kesulitan dengan tetap menimbang tradisi dan kondisi sosial mereka. Jika tidak syari'at akan membawa beban di luar daya manusia. Sesuai dengan pendapat Hasbi Ash-Shiddieqy tentang Asas Kemaslahatan Manusia, yang berarti Hukum Islam berkembang seiring dengan kehidupan manusia dan mereduksi sesuatu yang ada di lingkungannya. ${ }^{43}$

Asas Nafyul Harâji berarti meniadakan kepicikan. Artinya, Hukum Islam dibuat dan diciptakan itu berbeda-beda dalam batas-batas kemampuan para mukallaf. Namun, bukan berarti tidak ada kesukaran sedikitpun, sehingga tidak ada tantangan, tatkala ada kesukaran yang muncul, bukan hukum Islam itu digugurkan melainkan melahirkan rukhsakh..$^{44}$ Istilah rukhsakh memang berarti terbebasnya umat dari beban yang berat.

Menurut Abdul Hamid Hakim dalam al-Sulâm dikatakan bahwa rukhshak $\underline{h}$ merupakan :

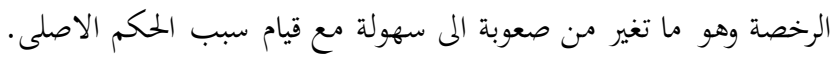

"Rukhshakh adalah sesuatu yang berubah dari kesukaran kepada kemudahan beserta adanya sebab hukum asal" ${ }^{45}$

Secara garis besar, rukhsakh terbagi menjadi dua. Pertama, rukhsakh saat menghadapi kesulitan di luar batas kemampuan fisik manusia, seperti penyakit yang mem-

\footnotetext{
${ }^{41}$ Ibid. hal 209-210

${ }^{42}$ Syahrul Anwar. Ilmu Fiqh \& Ushul Figh, (Bogor: Ghalia Indonesia, 2010) hlm. 54

43 lbid

${ }^{44} \mathrm{lbid}$.

${ }^{45}$ Abdul Hamid Hakim, al-Sulam, (Jakarta: Sa'adiyah Putra, tt). HIm. 10
} 
bawa manusia tidak dapat memenuhi rukun shalat sebagaimana mestinya atau yang mengurangi kemampuan dalam menunaikan puasa. Kedua, rukhsakh yang berlaku pada kesulitan yang masih dalam batas kemampuan manusia. Rukhsakh seperti ini dibedakan lagi menjadi dua sifat, yaitu rukhsakh yang dianjurkan, terlepas dari ada atau tidak adanya kesulitan sehingga hukumnya dianggap sunnah. Misalnya menjama' sholat di Arafah dan Muzdalifah ketika menunaikan haji. Dan rukhsakh yang tidak menjadi tuntutan secara khusus tetapi merupakan kemudahan dan jalan keluar dari kesulitan. Hukumnya tetap mubah (diizinkan) sehingga seseorang dapat saja memilih rukhsakh atau menempuh 'azimah (hukum semula) ketika mengalami kesulitan semacam ini. Contoh yang relevan dengan kriteria ini adalah jika seorang sedang mengadakan perjalanan tanpa kesulitan sedikitpun, maka ia dapat memilih berbuka atau tidak, atau meng-qashar sholat atau tidak. ${ }^{46}$

Al-Syatibi memandang rukhsakh lebih utama dipilih daripada 'azimah jika faktor kesulitan yang dihadapi manusia dapat merusak kemaslahatan yang bersifat dharuri (primer). Karena Asas qillatu taklif yang berarti menghilangkan beban taklifi, artinya hukum Islam itu tidak memberatkan pundak mukalaf dan tidak menyukarkan. Dalam keadaan seperti ini, ada dua kesalahan bagi siapa yang tidak mau memilih rukhsakh, pertama, menolak rukhsakh berarti menentang karunia Allah, kedua, ia telah menutup pintu kemudahan yang diberikan oleh syari'at kepadanya. ${ }^{47}$

\section{Peran Kaidah Fiqh dalam Pengamalan Hukum Islam}

Para imam madzhab dalam mengistinbathkan suatu hukum memiliki pola pikir tertentu yang dapat dijadikan aturan pokok, sehingga hasil istinbath-nya dapat dievaluasi secara objektif oleh para pengikutnya. Kaidah-kaidah dasar merupakan acuan merupakan acuan dalam ber-istinbath. Dengan demikian dalam tataran epistemologi, kaidah fiqhiyah berfungsi sebagai alat untuk mengetahui dan menelusuri pola dan kerangka berpikir para imam dalam ber-istimbath, sekaligus dapat diketahui titik relevansi antara ijtihad yang satu dengna yang lain. Akhirnya, dapat diketahui metode yang digunakan oleh para imam madzhab dalam beristinbath hukum. ${ }^{48}$

Pada tataran aksiologis, qawa'idul fiqhiyah berfungsiuntuk memudahkan mujtahid dalam meng-istinbathkan hukum yang bersesuaian dengan tujuan syara dan kemaslahatan manusia, karena dengan adanya kaidah tersebut, para mujtahid dapat menggolongkan masalah serupa dalam lingkup satu kaidah. Sebagaimana dinyatakan Abdul Wahab Khalaf bahwa nash-nash tasyri' telah mensyariatkan hukum terhadap berbagai macam undang-undang, baik mengenai perdata, pidana, ekonomi, dan undang-undang dasar, telah sempurna dengan adanya nash yang mendapatkan prinsip umum dan qanun

\footnotetext{
${ }^{46}$ Hamka Haq, Al-Syatibi: Aspek Teologis... hlm. 212

${ }^{47}$ Hamka Haq.. hlm. 212-213

${ }^{48}$ Syahrul Anwar. Op. Cit. hal 125
} 
qanun tasyri' yang kulli, yang tidak terbatas terhadap suatu cabang undang-undang, dibuat demikian agar prinsip-prinsip umum qanun-qanun yang mulia ini menjadi petunjuk bagi mujtahid dalam menetapkan hukum dan menjadi pelita di bawah sinar nyala api untuk mewujudkan keadilan dan kemaslahatan umat.

Diantara nash-nash tasyri' ada yang telah menetapkan prinsip-prinsip umum dan qanun-qanun kulliah yang menerangi undang-undang mengandung nash tasyri', yang menetapkan hukum asasi dalam cabang figh yang bersifat amali. Ungkapan tersebut menjelaskan bahwa lapangan fiqh begitu luas, karena mencakup berbagai hukum furu'. Oleh sebab itu, perlu adanya kristalisasi hukum yang berupa kaidah kulli yang berfungsi sebagai klasifikasi masalah-masalah furu' yang terbagi dalam berbagai bidang, dan terkumpul dalam satu bentuk. ${ }^{49}$

Fungsi qawaid fiqhiyah adalah agar para mujtahid dapat mengistinbathkan hukumhukum syara dengan baik dan benar, orang tidak akan dapat menetapkan hukum dengan baik apabila tidak mengetahui kaidah figh. Fungsi kaidah fiqh seperti ini banyak tersirat dalam beberapa pernyataan fuqaha yang menyatakan bahwa barang siapa mempelajari ushul maka ia telah sampai kepada maksud, dan barang siapa mempelajari qâwaid maka selanjutnya ia mencapai maksud. Atau secara khusus, Jalaluddin al-Suyuthi mengatakan bahwa ilmu al-asbah wa nadhair (qawâid fighiyah) merupakan ilmu yang agung, dengannya dapat diketahui hakikat fiqh, tempat diperolehnya, tempat pengembalian, dan rahasia-rahasia. Lebih lanjut ia mengatakan, dengan ilmu itu, orang akan lebih unggul dalam memahami dan menghayati figh sekaligus mampu untuk menghubungkan dan mengeluarkan hukum, serta mengetahui hukum-hukum masalah yang tidak tertulis, dan hukum-hukum peristiwa yang tidak ada habisnya sepanjang masa.

Qawâid fighiyah berfungsi untuk membina hukum islam. Hal ini ditegaskan oleh Hasbi Ash-Shiddieqy, yang menyatakan bahwa qawaid fighiyah berfungsi untuk memelihara ruh Islam dalam membina hukum, mewujudkan ide-ide yang tinggi, baik mengenai hak keadilan, persamaan, maupun dalam memelihara mashlahah, menolak mafsadat serta memperhatikan keadaan dan suasana. ${ }^{50}$

Pembinaan hukum ini dapat terlaksana melalui qawaid al-fiqhiyah karena menjadi pedoman untuk menetapkan hukum setiap peristiwa fiqh, baik yang telah ditunjuk oleh nash yang sharih maupun yang belum ada nash-nya sama sekali. Oawaid fiqhiyah disamping berfungsi sebagai tempat baagi para mujtahid mengembalikan seluruh seluk beluk masalah fiqhiyah, juga sebagai dalil untuk menetapkan hukum masalah-masalah baru yang tidaak ditunjuk oleh nash yang sharih, namun sangat memerlukan jawaban untuk ditetapkan hukumnya.

Qawaid fiqhiyah yang bersifat kulli itu akan mengikat atau mengekang furu yang bermacam-macam, dan meletakkan furu itu dalam satu kandungan umum yang lengkap,

\footnotetext{
${ }^{49}$ Ibid. hal 126

${ }^{50}$ lbid. hlm. 127
} 
karena hakikat qawaid fiqhiyah adalah himpunan hukum-hukum syara yang serupa atau sejenis, lantaran adanya titik persamaan atau adanya ketetapan fiqh yang merangkaikan kaidah tersebut.

Masyarakat Arab berada dalam wilayah yang tertinggal di antara bangsa-bangsa yang memiliki budaya tinggi, seperti bizantium dan sasanian, yang ribuan tahun lebih membangun suatu struktur kebudayaan kompleks dan hierarkis sosial feodalistik dalam tataran imperium raya. Keadaan seperti itu, melahirkan suatu corak madzhab hukum yang penalaran-penalarannya sangat didominasi oleh penalaran induktif atas varianvarian hukum yang kemudian diikat dalam sebuah konsistensi yurisprudensi, yang kemudian dikenal dengan qawaid fiqhiyah. Abu Hanifah dikenal sebagai tokoh utama yang memberikan bangunan hukum secara khas, yang kemudian dikenal dengan madzhab Hanafiyah. Dalam tradisi kultur Khufah, madzhab ini dikenal dengan madrasah ahl ra'y. metode istihsan merupakan cirri khas dari madrasah ahl al-ra'y ini. Hal ini menunjukkan bahwa madrasah ini sangat memperhatikan fleksibilitas hukum yang berdasarkan atas tujuan hukum. ${ }^{51}$

Dari latar belakang historis inilah lahir adanya dua perbedaan pendekatan terhadap syari'ah, pendekatan pertama lebih berorientasi pada semangat hukum (qawaid fiqhiyah), pendekatan kedua lebih berorientasi pada prosedur formal metodologi dari dalil-dalil deduktif, sehingga banyak melahirkan kaidah-kaidah ushuliyah yang didominasi oleh pendekataan kebahasaan, dan metodologi yang banyak menyerap kaidah-kaidah formal dari filsafat dan qiyas.

\section{Simpulan}

Dari paparan tersebut di atas, diperoleh kesimpulan bahwa secara epistemologis kemashlahatan perseorangan dapat digali melalui pemahaman dan analisis terhadap dua sumber hukum Islam (al-Qur'an dan al-Sunnah) tentang kemudahan-kemudahan dalam menjalankan ketentuan hukum yang ada didalamnya seperti dalam surat al-Baqoroh ayat 185 dan 286, dengan menggunakan kaidah ushul fiqh dan kaidah fiqh untuk menjelaskan keduanya.

Hadits Nabi ضرار ض ال ضر ولا merupakan landasan hukum yang dapat memberikan keterangan tentang kemashlahatan individu yang bisa dijadikan standar dari kemashlahataan umum. Dengan melihat kepada faktor illat hukum pada setiap individu. Hukum dapat diterapkan hanya kepada orang yang mempunyai persamaan dalam illat hukum. Apabila seluruh manusia memiliki illat hukum yang sama maka hukum dapat di berlakukan kepada seluruh manusia itu. 


\section{Daftar Pustaka}

An-Na'im, Abdullah Ahmed, 2011. Dekontruksi Syari'ah, Yogyakarta: LKis Grup.

Anwar, Syahrul. 2010. Ilmu Fiqh \& Ushul Fiqh, Bogor: Ghalia Indonesia

Azizy. A. Qodri, 2006. Reformasi Bermadzhab, Jakarta: Teraju, cetakan ke-5,

Dahlan, Moh. 2013. Paradigma Ushul Figh Multikultural Gus Dur, Yogyakarta: Kaukaba,

Departemen Agama, 1992. Al-Qur'an dan Terjemahannya, Jakarta: Gema Risalah Press

Djazuli. A. 2010. Ilmu fiqh, Jakarta: Kencana Prenada Media Grup, cetakan ke-7.

Fanani, Muhyar, 2010. Fiqh Madani: Kontruksi Hukum Islam di Dunia Modern, Yogyakarta: Lkis.

Fuad, Mahsun, 2005. Hukum Islam Indonesia dari Nalar Partisipatoris Hingga Emansipatoris, Yogyakarta: Lkis

Hakim, Abdul Hamid, T.Th . al-Sulam, Jakarta: Sa'adiyah Putra,

Haq, Hamka. 2007. Al-Syatibi: Aspek Teologis Konsep Maslahah dalam kitab AlMuwafaqat, Jakarta: Erlangga

Ibrahim, Duski, 2008. Metode Penetapan Hukum Islam, Membongkar Konsep Al-Istiqra AlMa'nawi Al-Syatibi, Jogjakarta: Ar-Ruzz Media

Machasin, 2011. Islam Dinamis Islam Harmonis, Yogyakarta: Lkis.

Manan, Abdul, 2006. Reformasi Hukum Islam, Jakarta: PT. Raja Grafindo Persada

Mas'udi, Masdar Farid, 2013. Syarah UUD 1945 perspektif Islam, Jakarta: PT. Pustaka Alvabet, Edisi Baru

Mawardi, Ahmad Imam, 2010. Figh Minoritas: Fiqh al-Aqalliyat dan evolusi Maqashid alSyari'ah dari konsep ke pendekatan, Yogyakarta: Lkis

Mubarok, Jaih, 2000. Sejarah dan Perkembangan Hukum Islam, Bandung: Remaja Rosda Karya,

Qaradhawi, Yusuf Al-. 2000. Hasan Al-Nadwi Dalam Kenangan Yusuf Al-Qaradhawi. Jakarta: Kafila Press.

Salman, Otje, 2010. Filsafat Hukum. Bandung: PT. Refika Aditama

Sardar, Ziauddin. 2005. Islam Tanpa Syariat, ed. Abdul Mu'ti dan Ahmad Najib Burhani, Jakarta: Grafindo Khazanah IImu

Shihab, Quraish, 2009. Membumikan Al-Qur'an, Bandung: PT. Mizan Pustaka.

Shimogaki, Kazuo, 2011. Kiri Islam, Antara Modernisme dan Postmodernisme, Yogyakarta, Lkis, Cet. VIII.

Umar, Hasbi. 2007. Nalar Figh Kontemporer (Jakarta: Gaung Persada Press.

Zuhaili, Wahbah Az-. 2005. Kebebasan dalam Islam, Jakarta: Pustaka Al-Kautsar. 
90 | Asy-Syari'ah Vol. 19 No. 1, Juni 2017 